\title{
Challenges in Teaching English to Young Learners: Global Perspectives and Local
}

\section{Realities}

\section{Introduction}

The widespread introduction of languages in primary schools has been described by Johnstone (2009:33) as 'possibly the world's biggest policy development in education', with English being the language most commonly introduced. There are several reasons for this trend. First, it is often assumed that it is better to begin learning languages early $(\mathrm{Y} . \mathrm{Hu}$, 2007; Nunan, 2003). Second, economic globalisation has resulted in the widespread use of English and many governments believe it is essential to have an English speaking workforce in order to compete (Enever \& Moon, 2009; Gimenez, 2009; Hu, Y., 2007). Third, parents want their children to develop English skills to benefit from new world orders and put pressure on governments to introduce English to younger children (Brock-Utne \& Holmarsdottir, 2004; Enever \& Moon, 2009; Gimenez, 2009).

In parallel with this expansion, there has been increasing criticism of the growth of English as a global lingua franca, in particular the political and social implications. Publications by Block, Gray and Holborrow (2012), Coleman (2011), Coupland (2012) Edge (2006) and Kumaravadivelu (2011) have all challenged understandings of the place of English, how it has reached its current level of popularity, whose interests the rise of English serves and the status of different world Englishes. Such discussions call into question the underlying premises on which the introduction of learning English at an early age are predicated (see also Piller and Cho, 2013). Edge (2006) and Kumaravadivelu (2011) in particular are also highly critical of wholesale adoption of western approaches to language teaching which support the spread of English while ensuring Western countries continue to benefit from it. 
Against this background, teachers of young learners around the world must daily fulfil the tasks of instructing their students, often being required to use a pedagogic approach which is alien to many, and having to persuade their students of the value of learning English. .

The research reported here is part of a larger study investigating global practices in teaching young learners (Authors, 2,1 and 3, 2011). The aim in this article is to identify the challenges faced by teachers of primary English both globally, across the total number of countries involved in the study, and more locally, in five of these countries located in different continents. Our aim is to portray overall trends but also to explore local variation and possible reasons for this variation. Specifically, this research responds to two research questions:

1. What are teachers' perceptions of the challenges they face in teaching English to young learners?

2. What challenges are experienced globally and locally?

\section{Challenges in teaching English to Young Learners}

The literature on teaching English to young learners has identified a number of pressing challenges. One is that English is often introduced as a compulsory subject at primary school without due consideration of who will teach it. In some countries a severe shortage of trained primary school teachers of English is reported (G. Hu, 2005; Y. Hu, 2007; Kirkgöz, 2009; Nunan, 2003; Nur, 2003). Teachers may therefore find themselves teaching English either without adequate training in teaching young learners in general or in teaching English to young learners in particular. The situation is especially acute in poor or rural areas.

One of the most complex of the policy decisions affecting young learner classrooms concerns pedagogy. The spread of English as a lingua franca has given rise to the belief that learners need to acquire communication skills rather than knowledge about English. As a result, more recent young learner curricula have emphasised communicative competence. In 
East Asia, this has often led to the introduction of some form of Communicative Language Teaching (CLT) or Task-Based Learning and Teaching (TBLT), for example, in Korea (Li, 1998; Mitchell \& Lee, 2003; Ahn, 2011), Hong Kong (Carless, 2004; Tinker Sachs, 2009), China (G. Hu, 2002), and Thailand (Prapaisit de Segovia \& Hardison, 2008). However, teachers may find it challenging to introduce these new approaches for several reasons. As Enever and Moon (2009) point out, CLT is a pedagogical approach developed in western countries to teach adults in small, well-equipped classrooms. It may not, therefore, be appropriate for teaching large groups of children in classrooms where resources are limited. Furthermore, as teachers may receive only basic training in the underpinning theory and practical applications, they may struggle to implement it effectively (Butler, 2005; Littlewood, 2007). The introduction of TBLT has been beset with similar problems (Carless, 2004; Littlewood, 2007). These imported approaches can conflict with educational traditions, or what Jin and Cortazzi (2003) call 'cultures of learning' (see, for example, Baker, 2008; G. Hu, 2002; Littlewood, 2007).

Linked to policies about pedagogy is the issue of resources. In some countries such as South Korea (Butler, 2004) and Malaysia (Pandian, 2003) textbooks are prescribed. In other countries, teachers can choose from government-approved books, for example, in Singapore (Mee, 2003) and in China (G. Hu, 2005). Given the global prevalence of early English learning, it is a matter of concern that in many countries, appropriate books are either not available (Hoque, 2009; Y. Hu, 2007; Mathew \& Pani, 2009)or are not used in the classroom (İnal, 2009; Nunan, 2003).

Other resources may also be unavailable in primary schools. In Li’s (1998) study South Korean teachers complained that there was insufficient funding for the equipment and facilities needed for learner-centred teaching, a point also made by İnal (2009) for Turkish 
teachers . While technology to support English teaching has clearly developed greatly in recent years, teachers have not always been able to access its benefits.

Another potential challenge for teachers concerns the level of English they require. Teachers' low proficiency levels, or their lack of confidence in their ability, is consistently identified in the literature (see, for example, Ahn, 2011; Baker, 2008; Ghatage, 2009; Kuchah, 2009; Littlewood, 2007). Many teachers believe that CLT demands particular classroom procedures, such as teaching in the target language, which causes anxiety and leads to their questioning their competence, particularly their speaking and listening skills (Kuchah, 2009).

In many parts of the world, large classes are a common challenge (Ho, 2003; Wedgwood, 2007; Shamin, 2012), causing teachers to believe it is difficult or impossible to introduce learner-centred teaching because, for example, they cannot closely monitor students' language use (Li, 1998) or use pairwork and groupwork (Hoque, 2009). A related issue is the problem of control and discipline (Butler, 2005; Littlewood, 2007); Carless (2004) argues that the noise produced during speaking activities can be problematic when the local preference is for quiet and orderly classrooms.

It can also be difficult to motivate learners. In many EFL contexts, children may struggle to understand the relevance of learning English as they have little contact with speakers of the language, particularly in rural areas (Ho 2003; Li, 1993).

Government policies and curricula that typically advocate teaching communicatively are often incompatible with the demands of national examinations ( Li, 1998; Littlewood, 2007) which often focus on grammar and vocabulary. Commentators such as Kunnan (2003) have noted the tendency to "'teach to the test"...with less time devoted to activities that are not part of the test' (p.786). This backwash/washback effect may have more impact at 
secondary level (Gorsuch, 2000), although it has been identified at primary level too (for example, İnal, 2009).

Having highlighted the key challenges identified in the literature, the research methodology and procedures of the current study are now presented.

\section{Research Methodology}

A mixed-methods approach was adopted for the study (see, for example, Richards, Ross and Seedhouse, 2012). Johnston et al. (2007) argue that mixed methods research 'combines elements of qualitative and quantitative research approaches (e.g. use of qualitative and quantitative viewpoints, data collection, analysis, inference techniques) for the broad purpose of breadth and depth of understanding and corroboration' (p.123). In line with Morse (2010), a QUAN- qual design was adopted, where QUAN represents quantitative methods and comprises the core component, in this instance a survey. The qual component is the supplementary approach and comprises data from an open question on the survey filtered by country, and observations of and interviews with five teachers of young learners in five international locations.

The mixed methods approach allows for a framework of reference that acknowledges both the global and the local. The survey provided global results across 142 countries and uncovered the major challenges in teaching young learners as reported by the 4,459 teachers who responded. The qualitative data illustrate the variation in challenges that can occur at the local level and compares them to the global.

The cross-sectional survey drew on non-probability 'convenience' sampling ${ }^{1}$. The survey was provided both electronically through Survey Monkey, and via hard copy to

${ }^{1}$ The distribution of the survey was facilitated through local offices of the British Council, who funded the research, and the researchers' professional contacts. 
accommodate teachers who had limited or no access to the internet (the data on the hard copy questionnaires were later transferred to electronic format). This approach allowed for large and geographically diverse samples of data to be collected in an efficient, economic and standardised manner (de Vaus, 2002; Dörnyei, 2009).

In relation to this study, the disadvantages of opportunistic sampling need to be recognised. The survey reflects reported practices only and cannot claim to be representative because of the unevenness of responses across countries. This type of sampling also does not provide a standard ratio of respondents to the number of employed primary school teachers in a country. However, increasingly opportunistic sampling is acknowledged as common in studies of this kind (see, for example, Williams et al. 2010) as it is intended to fit the purpose of providing illustrative and non-generalizable portrayals of respondents' viewpoints (Reis \& Judd, 2000).

Here, we focus on two sections of the survey. The first is a ranking question in which teachers were asked to order interventions which would 'most improve learning and teaching' in their own context. This question aimed to uncover areas that teachers might consider problematic and therefore locally challenging. The content for the ranked items was taken from the literature discussed above and comprised the following: better access to resources such as books and materials (Hoque, 2009; Mathew \&Pani, 2009); fewer tests and exams (Littlewood, 2007); better access to new technologies such as DVDs or computers (Ghatage, 2009); training in new language teaching methodologies (Ahn, 2011; Prapaisit de Segovia \&Hardison, 2008); improvement in own level of English (Butler, 2004; Kuchah, 2009); smaller classes (Wedgwood, 2007; Shamin, 2012); starting English at an earlier age ( Enever \& Moon, 2009); more hours of English ( Pinter, 2006). The responses were then analysed descriptively using a Survey Monkey tool.

The second section of the survey data of interest is an open question which asked 
teachers, 'Which aspect or aspects of your job do you find the most challenging?' This question attracted 1,931 responses. Given the large number, a corpus tool was considered the most appropriate for analysis. First, the responses were collated and then spelling mistakes corrected using Word 2010. Through repeatedly reading the data, frequently used key words were identified, such as 'discipline', 'motivation' and 'grammar'. Wordsmith was used to search for these keywords and to create the preliminary categories. Further categories were created through searching the remaining data and identifying further key words. If more than one challenge was included in the response, each challenge identified was categorised separately. All items were considered, although this resulted in some categories with very small numbers (for example, both 'after school activities' and 'appreciation' only featured twice in each case). The resulting concordance lines were carefully examined and statements which appeared in more than one category were removed. A Chi square test was then administered which found that the results were statistically significant and showed that informants preferred some categories over others and that the measures, therefore, did not occur by chance.

Observations of and interviews with five teachers, who had completed the survey, took place in five different countries: Colombia, Italy, South Korea, Tanzania, and the United Arab Emirates. (The countries were chosen to include major continents so as to give illustrations from diverse perspectives across the world.) The findings from these qualitative data were then combined with the survey responses which had been filtered for each individual country to produce five separate accounts. For the purposes of this article, we regard these as localised exemplifications and the term 'case study' is used to refer to them.

A consistent methodology was used in all five locations. First, teachers were approached either because they had been suggested by local contacts or because they had indicated in the survey that they were willing to be observed. They were then asked in an 
initial interview for preliminary information about the class/students, the purpose and plans for the lesson, and for any other information relevant to the observation. They also provided relevant documents (policy and syllabus documents and classroom materials). Depending on the teacher's availability, at least one lesson was observed in each site and each observation was audio-recorded. Notes were made by the researcher at the site and later written up as fieldnotes. After the observations, further interviews were conducted. Transcripts were made of all the interviews.

In order to analyse the data, first results from the closed question and from the open question were filtered by country to identify the local challenges. Then, fieldnotes and interview transcripts were examined to identify the challenges faced by the five individual teachers. $^{2}$

\section{Findings}

Before discussing the survey results, demographic information is warranted in order to understand in more detail the characteristics of the questionnaire respondents. The vast majority were female (80.4\%). Most worked in state schools (approximately $68 \%$ ), with $27 \%$ working in the private sector and the rest choosing non-specified 'other'. $74 \%$ of schools were located in urban areas. Regarding the teachers' ages, approximately a third were in their 30s while just over a quarter were in their 20s and a quarter in their 40s. Over half had been teaching English for less than ten years and over two-thirds had been teaching English to young learners for less than ten years. In terms of education, approximately $73 \%$ had at least a bachelor's degree.

\footnotetext{
2The researchers followed The British Association for Applied Linguistics' (2006) ethical guidelines for applied linguistics research, including informed participant consent, with participants being assured of anonymity and confidentiality. Full ethical approval was also gained by the Ethics Committee of the researchers' institute. Full details of the research design can be found in Authors 1,2,3(2011).
} 


\section{Teachers' perceptions of the challenges}

The first research question asked:

What are teachers' perceptions of the challenges they face in teaching English to young learners?

An initial indication of the challenges faced is shown in the results from the ranking question, which asked teachers what would most improve learning and teaching in their classrooms. The results are given in figure 1:

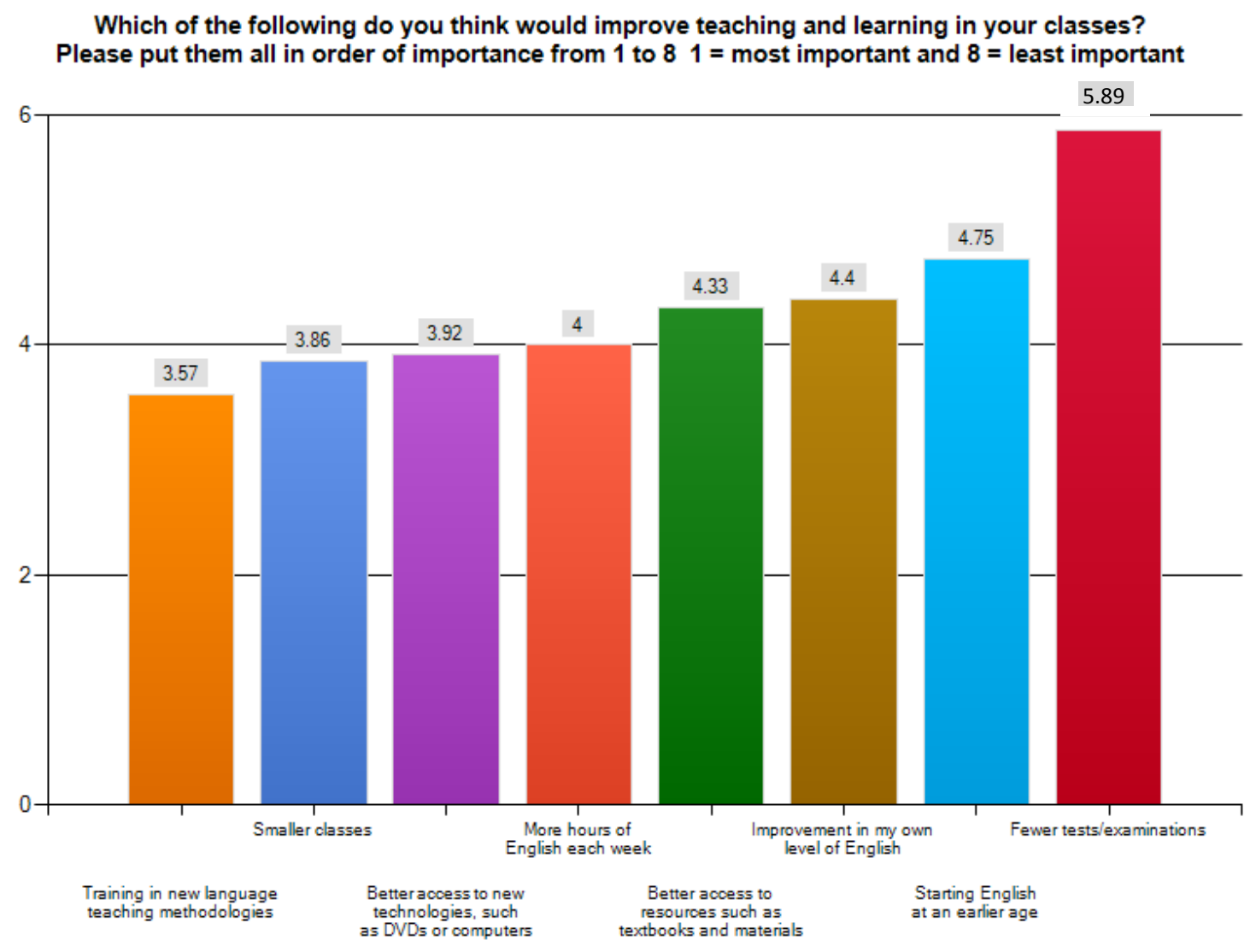

Figure1: Ranking of factors that would improve learning and teaching

It can be seen from this table, where columns on the left represent the most important and those on the right the least important, that fewer tests and examinations is considered the least important factor in improving learning and teaching to a noticeable extent. Starting English at 
an earlier age is considered the second least important overall, while better access to paperbased resources and improvement in levels of English attract a similar number of responses but are still considered less important that other factors.

Training in new language teaching methodologies is ranked as the most important globally, by a fairly sizeable margin. Smaller classes, better access to new technologies and more hours of English attracted similar number of responses and were also considered important by teachers. These results will be discussed in further detail below.

More in-depth information about teachers' perceptions of the challenges they face was obtained from the open question which asked 'Which aspect or aspects of your job do you find the most challenging?'. From the corpus analysis, the following descriptive table was generated:

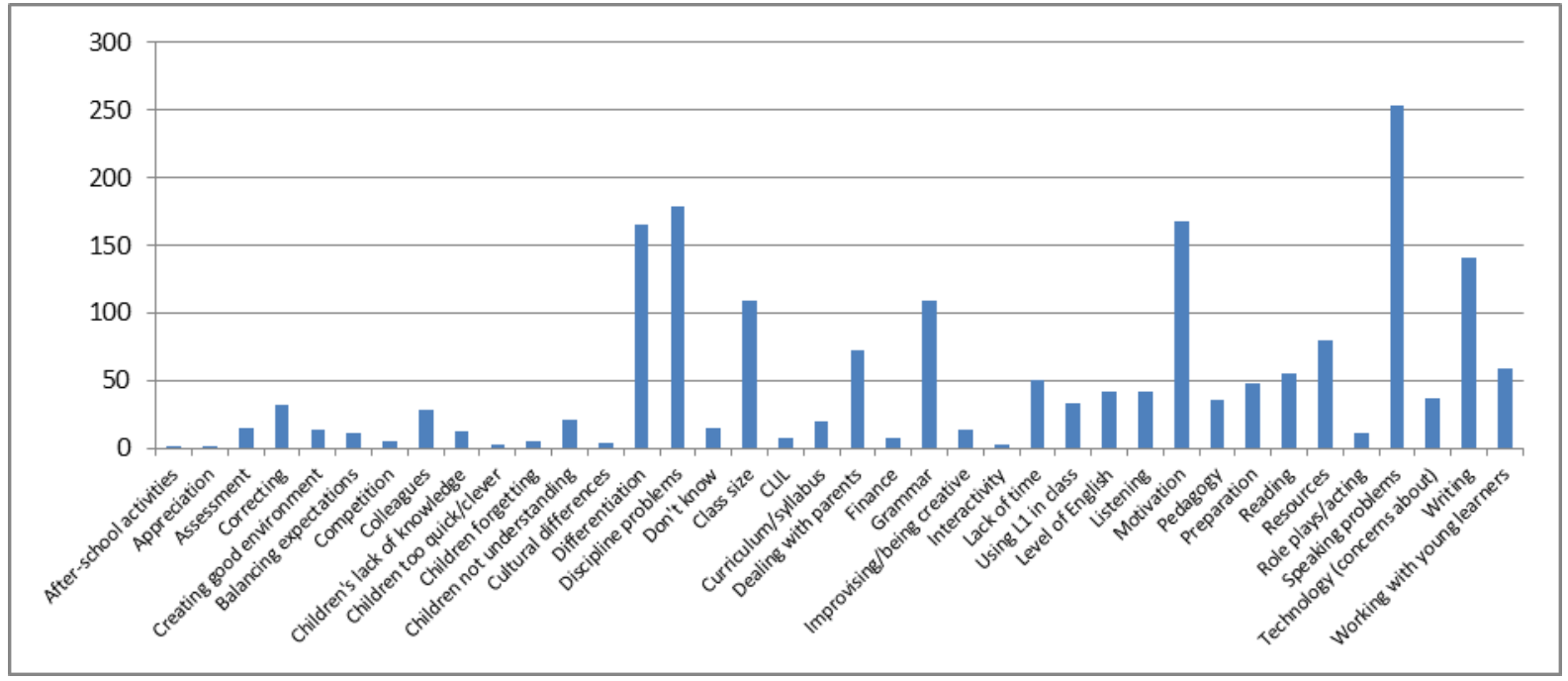

Table 2 Challenges identified by teachers

The category that attracted the most comments was 'speaking problems' with 254 comments. This category comprised teaching speaking in general (143) and teaching pronunciation in particular. This was followed by 'discipline problems' (179), which comprised 'discipline problems' (77); 'behaviour problems' (55) and 'classroom 
management' (47). Then came 'motivation' (168) and next 'differentiation' (166) in which was grouped 'different/mixed levels/abilities/aptitudes/abilities' (65); 'weak students'(33); 'learners with problems/difficulties' (29); 'meeting students' needs' (19), 'individual differences'(12); and 'special needs' (8). 'Writing' was in fifth place with (141) comments divided between 'teaching writing' (125) and 'spelling' (16). 'Grammar' and 'class size', both attracted 109 comments.

Below we discuss the specific challenges which were perceived by teachers as most important. We include comments from responding teachers, which are quoted verbatim.

\section{Speaking}

The challenge most frequently identified was teaching speaking.This result is somewhat surprising as classroom observations suggested that children were enthusiastic speakers. However, clearly teachers struggle to teach this skill. Previous research has identified teachers' level of English (see, for example, Ahn, 2011; Baker, 2008; Ghatage, 2009; Kuchah, 2009; Littlewood, 2007) and language teaching methodologies (for example, Ahn, 2011;Carless, 2004; Ho, 2003; Tinker Sachs, 2009) as being problematic. However, the challenges of teaching speaking as a skill until now have not been identified.

The most common comments were about getting children to speak, for example:

Making them speak and persuade them that speaking English is something they are able to do

It could be that many children are reluctant to speak in front of their classmates, particularly in a foreign language, as it can be extremely face threatening.

There were also several comments which focused on creating an English only classroom: 
Make them communicate only in English in the classroom with me and their peers.

This theme was picked up in, 'Using L1 in class', where 13 of 33 comments complained of the problems of students translating from one language to another or using L1 in class, and in 'Pronunciation' where teachers stated it was difficult to teach 'good', 'correct' and 'perfect' pronunciation. Recent research is critical of the target language only approach, suggesting it does not represent the multilingual realities of many children (see, for example, Creese \& Blackledge, 2010;Garcia, 2009); and that the students' first language can play a strong pedagogic role in teaching the target language (for example, Butzkamm, 2003;Macaro, 2005). There is also much criticism of the view that learners should aim for "native-speaker like' production (see, for example, Jenkins, 2000). Nevertheless, both positions seem to be prevalent among a number of survey respondents and in the five classes we observed, where very little first language was used, even when the teacher's English was not strong.

\section{Discipline.}

Discipline attracted the second largest group of comments. Discipline problems were linked to the age and sex of the students, differentiation, parental attitudes, inexperience, not sharing the learners' first language, and keeping the students motivated. For example, one teacher commented:

Discipline as I am teaching in a boys school.

While another stated:

Unruly children who lack discipline from home is a major challenge.

The teachers we observed also raised the issue of discipline and used various strategies for maintaining it.

\section{Motivation .}


Both the number and type of comments about motivation tended to contradict many lay, and indeed, informed, ideas that young learners of English are intrinsically motivated and keen to learn. This comment expressed common concerns:

How to motivate students and make them love English

In line with previous research (Ho, 2003; Li 1998)some teachers believe that young learners do not understand the purpose of learning English, an attitude which may be exacerbated by their parents:

Parents' motivation, respect and importance given to learning English

The teachers seem to feel a strong sense of responsibility to motivate students, which can mean they expend a good deal of energy, both in planning a range of activities and in classroom teaching. Certainly in the classes we observed teachers worked very hard both before and during class to ensure the lesson was well-organised, involving and focused.

\section{Differentiation.}

The fourth largest category is differentiation, meaning that many teachers are dealing with students who are at different stages of learning and have different individual needs. Students are often perceived as not being strong at learning languages, or having a special educational need of some description. A number of comments revealed that children's knowledge of English may differ because some attend private English language classes outside school, a factor which Lamb (2011),Seargeant\&Erling (2011) and Chakraborty\&Kapur (2008) argue is widening the gap between rich and poor . It is important that the social and economic aspects of differentiation have gained attention in the recent literature. This study developed understanding in this area by uncovering the effects of differentiation on state school classrooms and the challenges it poses to teachers. 
In the 'weak students' category, teachers often conflated weakness with motivation, as in the following comment:

Teaching weak students who don't want to learn English.

In the 'learners with problems/difficulties' category, some teachers mentioned particular learning problems such as dyslexia and Attention Deficient Hyperactivity Disorder (ADHD), although generally problems were not specified.

These comments reveal a complex picture of teachers' attitudes to young children learning English: sometimes the child is labelled as the problem (for example, a 'weak' student) whereas for others it is responding to children that is considered problematic (for example, 'preparing from different levels of attainment').

\section{Writing}

Given that many children will be learning a new script when learning English, it is not surprising that writing also presents a challenge. Moreover, many children will be learning to write in English and in their first language, which means they are developing literacy in two languages simultaneously. Two aspects of writing concerned teachers in particular (apart from spelling, which taxes teachers of children learning English as a first language too): teaching children to write 'correctly' and teaching children to write 'creatively'. Certainly in our observations we witnessed both kinds of writing. The first, which generally comprised copying from the board, filling in gaps, or writing controlled sentences, while often done quite slowly and with some effort, was generally successful. Creative writing, on the other hand, where children were asked to complete a story or write their own sentences around a topic area for example, tests children to a far greater extent. Many children seemed unable to complete these kinds of tasks and others were not even able to begin them. Creative writing 
is often highly prized in western primary education as a means to help students to express themselves and to enjoy writing. It could be that teachers are adopting this 'communicative' pedagogy wholesale, but perhaps without the same success.

\section{Grammar}

Another key issue was 'teaching grammar (109 comments). Although many teachers identified 'grammar' as a challenge without further explanation, comments such as:

To explain difficult grammar categories (e.g. the difference between the present perfect and the past simple)

and:

In my personal opinion is grammar aspect because children become bored when teachers try to teach in this way.

were not uncommon. The fact that young learners between 7 and 11 are being taught 'grammar' is of particular interest. Given their age, the amount of English teaching they are receiving each week (usually less than two hours), and that they are often in large mixed level classes, the value of explicit grammar teaching might be questioned; yet as several comments show, it is clearly an aspect of some teachers' practice.

Of course, there may be good reasons for focusing on grammar. Cameron (2001) notes that some children benefit from 'skilful grammar teaching' (ibid: p.121). Similarly, Pinter (2011), reviewing a study by Harley (1998) which examined focus-on-form in a grade 2 immersion class of L2 French in Canada, concluded that "children were able to focus on form and derive benefits from an approach that focuses on grammar" (p.107).

\section{Class size}


In the ranking question, class size was identified as the second most important factor in improving teaching and learning in schools. While it is raised again in the open responses, it is not given the same prominence as other challenges with only 109 comments (maybe because teachers felt it had already been addressed in the ranking question). Class size is clearly more salient in state schools than in private schools, where numbers are generally lower; and as suggested by this teacher, class size might be indicative of other issues:

Big size class, poor teaching and learning conditions.

As mentioned above, class size is often linked to discipline ('big classes behaviour problems') and also with teaching mixed levels ('dealing with large classes with heterogeneous levels').

\section{Global and local challenges}

The results so far provide a global snapshot of teachers' views. However, the global level may or may not reflect local practices which are likely to vary according to particular contextual influences. In this section, therefore, we examine similarities and differences among the five country locations in order to respond to the second question:

What challenges are experienced by teachers of young learners globally and locally?

\section{Results from quantitative data.}

Table 1 below shows the results of the ranking question for each country:

\begin{tabular}{|l|l|l|l|l|l|}
\hline $\begin{array}{l}\text { Factors } \\
\text { (Listed in global order: } \\
\text { see Figure 1) }\end{array}$ & $\begin{array}{l}\text { Italy } \\
\mathrm{N}=555\end{array}$ & $\begin{array}{l}\mathrm{UAE} \\
\mathrm{N}=70\end{array}$ & $\begin{array}{l}\text { Tanzania } \\
\mathrm{N}=58\end{array}$ & $\begin{array}{l}\text { Colombia } \\
\mathrm{N}=182\end{array}$ & $\begin{array}{l}\text { South } \\
\text { Korea } \\
\mathrm{N}=125\end{array}$ \\
\hline $\begin{array}{l}\text { 1. Training in new } \\
\text { language teaching } \\
\text { methodologies }\end{array}$ & 2 & 2 & 4 & 1 & 2 \\
\hline
\end{tabular}




\begin{tabular}{|l|l|l|l|l|l|}
\hline 2. Smaller classes & 4 & 1 & 5 & 7 & 1 \\
\hline $\begin{array}{l}\text { 3. Better access to new } \\
\text { technologies }\end{array}$ & 3 & 3 & 6 & 2 & 6 \\
\hline 4. More hours of English & 6 & 5 & 7 & 4 & 4 \\
\hline $\begin{array}{l}\text { 5. Better access to } \\
\text { resources }\end{array}$ & 5 & 4 & 2 & 6 & 5 \\
\hline $\begin{array}{l}\text { 6. Improvement in level } \\
\text { of English }\end{array}$ & 1 & 7 & 3 & 3 & 3 \\
\hline $\begin{array}{l}\text { 7. Starting English at an } \\
\text { earlier age }\end{array}$ & 7 & 6 & 1 & 5 & 7 \\
\hline $\begin{array}{l}\text { 8. Fewer tests and } \\
\text { examinations }\end{array}$ & 8 & 8 & 8 & 8 & 8 \\
\hline
\end{tabular}

\section{Table 1: Results of ranking question by country}

In line with global responses, teachers across all five countries indicated that fewer tests and examinations were least likely to improve learning and teaching and therefore were far less of a challenge than other factors. Also relatively compatible was the importance of training in language teaching methodologies. Italy, UAE, Colombia and South Korea all ranked this factor as first or second. For teachers in four countries, better access to resources such as textbooks and materials was similarly ranked to the global response. The exception was Tanzania where teachers ranked this factor second, probably because even basic resources are scarce in many primary classrooms (see below).

More obvious variation can be seen in teachers' attitudes to more hours of English. While Colombia, South Korea and UAE show similar results to the global survey, in Italy and Tanzania more hours is less important. Likewise, teachers in Italy, UAE and Colombia show similar attitudes to better access to new technologies ranking it either second or third. Of note, South Korea and Tanzania both rank this factor sixth, presumably for very different reasons: in the former classrooms are already well resourced with new technology (see below). In Tanzania, on the other hand, access to technology is extremely limited and therefore likely to be considered by teachers as a remote if desirable possibility. 
Differences also characterise starting English earlier. South Korea, UAE, Colombia and Italy tend to follow the global trend. The exception is Tanzania where it is ranked first, perhaps because of the tradition of using English as the medium of instruction (Coleman, 2012) and the subsequent pressure teachers feel to complete the syllabus (see below) but also because of changes in language education policy (Authors 1,2 and 3).

The 'small classes' factor shows considerable variation against the global survey and among the five countries. In the UAE, where most classes are relatively small (20+), it was ranked first. In contrast, in Colombia, where classes are generally large (30+), and Tanzania, where they are very large (40+), smaller classes are not judged as important as many other factors. This finding illustrates the complex interplay of local realities and educational norms where notions of acceptable classroom behaviour and classroom roles may vary.

In the global survey, 'improvement to my own level of English' was ranked sixth, whereas three of the five countries (South Korea, Tanzania and Colombia) ranked it third and Italy ranked it first. One explanation may be that when the policy to introduce English was introduced, many Italian teachers had limited English skills but were required to teach it. South Korea experienced a similar situation until recently when policy dictated that all teachers of English must be qualified. In the UAE, however, this factor ranked seventh, possibly because of the reliance on expatriate teaching staff.

\section{Results from qualitative data}

\section{Colombia.}

Of 122 Colombian open responses, teachers highlighted developing speaking (18) as the greatest challenge. A number focused on pronunciation, such as the following: 
Help them to improve their pronunciation and avoid Colombian accents and intonation when speaking

The second largest category was differentiation (14) which included comments about level as well as ability. One teacher wrote:

Helping students with learning disabilities. However, I try connecting with them and challenge myself to help them improve their results.

This was followed by inadequate resources (14) and teaching writing (10). While, in line with global responses, motivation and discipline were also mentioned, Colombian teachers mainly appear concerned about developing productive skills and the lack of resources to assist them.

These concerns were echoed during the classroom observation, conducted in an urban primary school in a low socio-economic area on the outskirts of the capital. The Grade 4 class consisted of 32 children aged 8-9 years. The teacher moved "from room to room", bringing materials or equipment with him and he lamented that students' exposure to English was very limited:

Grade 4 , have two sessions. The class is 55 minutes... but in $3^{\text {rd }}$ grade and $5^{\text {th }}$ grade and pre-school, only one a week, so they have very few chance.

Reasons were that the school operated a morning and afternoon 'shift', English staffing was restricted and the school could not afford more teachers. He saw restricted hours as a major challenge to effective learning:

It would be wonderful to have more teachers and the best situation is that the children have every day the English class, because English is hard to learn.

Another challenge was access to materials, especially technology: 
I would like to have more materials, For example, I asked the director to give me a computer... but it is just expensive. We have materials, but they cannot write on the books so I give them photocopies.

Discipline was also sometimes a challenge.

The big challenge that I face in my class are when I find difficult students, that don't obey.

Classroom observation showed that students were indeed noisy, with many wriggling in their seats and chatting as he taught. However, most also appeared reasonably focused on the tasks which centred on comparison of adjectives (bigger, smaller, fatter, thinner), probably because the teacher worked hard to vary activities:

I tried to do different activities, songs and dialogues and writing exercises and puzzles, and I pasted pictures on the blackboard for the students to learn comparatives.

He saw discipline as linked to challenges to motivate students, especially given some reluctance to learn English: “Teacher, I think I will never go abroad”. He also saw motivation as his responsibility to make classes appealing and purposeful.

\section{Italy.}

Of the 333 comments from Italy, teaching speaking was the greatest challenge with 52 responses, reflecting the global trend. The second major challenge, which did not figure in the global responses, was Italian teachers' concern about their own levels of English. Of 45 answers on this issue, 28 focus on their spoken English. The other responses referred to lack of knowledge about English (6) and a general need to improve their English (11). One teacher wrote: 
In my opinion, it's very hard to speak English all the lesson.

Motivation was the third most common challenge with 41 responses, again following the global results.

Another contrast with the global data is that 45 teachers felt that the way they teach English is a challenge, with 30 comments on pedagogy and 15 on being creative. The comments below illustrate this point:

Find new ways to teach English better.

To teach the language playing.

Two further results are noteworthy. Fifteen teachers saw teaching Content and Language Integrated Learning (CLIL), an approach to language teaching which is developing in popularity, particularly in Europe, as challenging and 14 teachers found the lack time to teach English to be more of a challenge than the size of the classes, even though classes are often not that small.

The Italian case study teacher worked in a large primary school in a relatively affluent part of a small city in northern Italy and the classes observed were grades 3 and 5 . There were 20 students in each class. In response to the direct question about her biggest challenge, she replied:

The biggest challenge is to get them to learn.

However, a comment made in a subsequent interview revealed she faced similar challenges to teachers in other countries around the world:

And the most difficult thing is to get the children to talk, so you see all my efforts are to get them accustomed to talking a little bit. 
She went on to speak about the importance of treating each child as an individual. Her classescontained a number with learning difficulties or special educational needs. She spoke about the challenges of working with these children, indicating that differentiation is an issue. In the observation, she addressed this area in a number of ways, for example, children worked in groups and could earned points for good behaviour as well as using English (see too South Korea).She also ensured that children moved and sat in different areas for short periods of time so that they changed their focus and did not get too restless. As she said:

But I think cooperation helps them a lot. So good children help the other one. So I'm quite encouraging them to do things together, because the good ones can do the work anyway, and the other ones learn from their peers more than from me.

Nominating children to take different roles in the class such as library monitor and doing the lunch roll also encouraged participation and individual responsibility.

\section{South Korea.}

The results from South Korea largely reflect the global data although differentiation attracted most comments (10 out of 52), which overwhelmingly focused on level (cf. UAE below):

There are too big gap between fast learners and slow learners caused by private education.

Speaking and motivation each received 8 comments and discipline attracted 6 . Also attracting 6 comments was teachers' level of English, which did not emerge in the global data but was also a problem in Italy. One teacher suggested: 
Korean students' English proficiency is getting higher. I feel some burden about my own English proficiency.

The issue of level was also identified by the teacher in the interview who in response to a question about the biggest challenge she faced said:

there is severe level gap among kids, so I should meet all their needs, the low-level kids, they should be involved in the class, and the best kids should not be bored. So I should make all activities consider all the levels.

She also raised an issue that was not otherwise identified in the open responses: the native English teacher scheme:

We have native English speakers as assistants, they don't have certificate as a teacher, but some have. So even though they speak perfect English, they don't know how to ...to manage the kids...And co-teaching system sounds very ideal but in reality there is a lot of problems. If they don't understand each other's culture it's very difficult to communicate properly.

In countries such as Japan, Taiwan and Hong Kong, native English teacher schemes are common and similar issues have been reported by researchers in these contexts (for example, Jeon, 2009).

The class observed was a mixed grades (1 and 2) after school class in Seoul. During the observation the teacher employed a variety of strategies to maintain interest and motivation in all the children. For example, she changed activity frequently and used technology, such as a smartboard, and teaching aids such as mini whiteboards for the children to draw on. 
Like the Italian teacher, the Korean teacher also grouped the children. This ensured that children of different levels worked together and developed a sense of responsibility to each other and the group. Incentives such as points were awarded to the groups, as were sweets, for making contributions and answering questions.

\section{Tanzania.}

Of the 89 open question responses from Tanzania, speaking was again identified as the greatest challenge (18), followed by lack of resources (15) and large classes (13). The latter two differ from global trends but are unsurprising in an environment where large class sizes are very common and resources are limited, especially in state and rural schools. One teacher commented on resources:

Lack of teaching aids and equipments

Another focused on the effect of large classes:

High population of students in the class reducing good, efficient teaching/learning of English.

The observed classroom confirmed the significance of these challenges for Tanzanian teachers. Located in a rural environment, classroom facilities were basic, the main teaching tools being a blackboard and realia, supplied by the teacher, such as a football, a clay pot and a flower. The observed classes, grades 1 and 4, were small by Tanzanian standards with 45 children in each, but large by global standards where $93 \%$ of teachers reported classes of fewer than 40 . 
The teacher, who was the school's Head, had 40 years teaching experience, and had originally trained for two years. The syllabus was grammar-based reflecting the approach in national examinations. The teacher explained that she followed it by drawing exercises from a textbook as the basis for her activities.Her focus, however, seemed to be mainly on encouraging students to speak:

I have just to prepare conversation, they can discuss about things.

She criticised some of the younger teachers for not encouraging speaking in class:

Maybe she takes just the book and writes on the blackboard. They don't share with the pupils. That's why the class is difficult to talk. If the pupil takes a lot of time just to copy from the blackboard...sometimes she can understand what you say, but she can't talk. She can just write, keeping silent.

The teacher identified teachers' level of English as a problem and one of the reasons they did not encourage speaking in class: “They don't understand English and it is very difficult to teach for them".

The teacher met thechallenge of teaching a large class through lock-step instruction with choral repetition and drills. She maintained interest through constant elicitation and concept checking, a lively pace and high energy. As well as using realia, the teacher also addressed the lack of resources by writing substitution tables, for example, on large pieces of paper, which were held up at the front of the class by two children.

\section{The UAE.}

Of the 43 responses by UAE teachers to the open questiondifferentiation attracted most attention (7 comments), with five comments blaming the students for being 'weak' and only two suggesting, as in the South Korea data, that differences in level was the problem. 
Lack of time was the second most common challenge ( 5 comments) with the focus being on the mismatch between time available the amount of work required:

Trying to teach a full English course to students who are also learning Arabic and Islamic Studies each day, taking a big chunk of my teaching time out.

Motivation was also a problem with four comments. Other issues included discipline (3), resources (3), large classes (2), speaking (2), grammar (2), writing (2) and parents (2).

The school visited was in a rural part of the Emirates and was a 'model school', defined by the teacher thus:

It's a state school but the government, or our education council, is investigating more in these schools, which means they are well equipped technology-wise, facilitieswise.

The school, then, was not typical of schools in the region : there were between 15 and 17 children in a class, teachers were qualified (and in some cases experienced) and it was wellresourced.

When asked what he liked least about teaching young learners, the teacher's response chimed with responses to the open question:

Motivation. It's motivation. The worst thing that a teacher could experience is when he has no motivated students. This would kill him, especially if he is enthusiastic about his subject. And unfortunately this is the problem in the UEA schools. 
In this teacher's opinion, lack of motivation was due to Emirati children believing they did not need to learn English, an answer which was also given twice in response to the open question.

The teacher also discussed the importance of strong classroom management. His skills in this area were revealed in the observation. For example, in one class, when the students became over-excited in an activity that involved moving around the class, the teacher raised a 'STOP' sign, which caused the children to sit down immediately and put their heads on their hands. He also had a number of strategies for setting up pair and group work activities. Although he did not mention differentiation explicitly, it was apparent in the observation that meeting individual students' needs was a central tenet of his teaching approach as children were given different tasks according to level.

Of particular interest was the way in which he involved children in the organisation of the lesson, from running the PowerPoint presentation to taking the register. As he said:

Students have small attention span and the more activities you do inside the classroom will make them more involved in their lesson. I do a lot of hands-on activities. I believe in multisensory activities.

While challenges in the UAE mirror the global picture to some extent, motivation and differentiation are particular local challenges which require teachers to be skilled in planning and classroom management.

Overall these findings suggest that the challenges teachers face in teaching English to young learners are both myriad and, in many cases, common. In the next section, we discuss how these challenges might be met.

\section{Implications for teacher educators}


The global findings mirror, to some extent, themes highlighted in previous literature which has generally focused on specific contexts. However, the study reported in this article makes a significant contribution to our understanding of the challenges teachers face in two ways. First, it systematically documents and compares previously identified challenges across a range of global contexts. Second, it uncovers a number of areas that have either not been previously identified in the literature or have not attracted analytic attention.

One potentially significant finding is that most seem less concerned about tests and examinations than current literature would suggest. On the other hand, the data show there is a particular concern with language teaching methodology and with teaching speaking in particular. These findings may reflect current government policies which have introduced a focus on communicative approaches as a way of addressing the perceived need for an English proficient workforce in the global economy. This is a view which continues to grow despite recent literature highlighting how learning English might not be in the best interests of all (see for example Coleman 2011; Pillar and Cho 2013).

Learning and teaching in a communicative way also may represent a shift in educational culture from language learning as an intellectual discipline to language learning as a practical skill, with a particular emphasis on speaking. It could be therefore that the data shown here demonstrate a shift in teachers' concerns from passing examinations to developing students' linguistic competence in specific areas of language learning.

. Rather than introducing teachers to broad-based concepts of communicative language teaching or TBL, which research has suggested can be confusing (Butler, 2005; Ho and Wong, 2003; Littlewood, 2007), it might be more effective for teacher educators to focus on practical strategies for teaching the productive skills of speaking and writing. Teacher education programmes could include basic classroom management skills in setting up, 
monitoring, and feeding back on pair and group work, the kind of speaking and writing activities that are most effective with particular age groups and levels, and peer teaching that practises implementing speaking in the classroom. Noise and poor behaviour, which can result from interactive class work, particularly in large classes, could form part of the feedback discussions. Training in teaching writing skills should also consider the kind of writing young learners should do, particularly as they aresimultaneously developing motor and cognitive skills, and whether creative writing is a tenable choice.

Research data drew attention to teachers' concerns about their own levels of English. Survey responses reflected the assumption that classes should be conducted in English, something teachers considered a tenet of CLT (in most of the lessons observed, English was used almost exclusively). However, current research is challenging the hegemony of target language only classrooms (Brooks-Lewis, 2009; Conteh, 2007; Creese and Blackledge, 2010). Using English taxes not only teachers, in terms of explaining grammar and keeping control, but also children, leading to boredom and misbehaviour. In teacher education programmes, teachers could be asked to consider the use of local languages in the classroom and the pedagogic rationale for using them.

Teacher education should also focus on strategies for maintaining discipline, managing large classes and developing motivation. The classroom observations yielded examples of effective practice, but survey responses suggest teachers are struggling globally with these areas. They might be particularly acute for teachers new to teaching young learners whose expertise is in language learning and teaching rather than in primary school pedagogy.

Differentiated learning and teaching has developed considerably recently, both in terms of rationales for differentiation and in practical approaches (e.g. Author 1 and Mann, 
2011). How to work with mixed level students, with students with learning difficulties and with learners who are from challenging backgrounds should be part of any primary teacher's training. Most children can learn a second language to some level, but there are many reasons why children will resist doing so. Teachers should be given the opportunity to discuss the sociocultural aspects of language learning (Johnstone 2009) as well as appropriate strategies for teaching languages effectively to young learners with different needs.

The fact that policy changes in many countries have mandated the teaching of a second language (usually English) often without due consideration of adequate resourcing, means that research into how much language proficiency a teacher of young learners needs in order to be effective is vital (e.g. Enever 2011). This research needs to take into account the amount of English children learn each week as well as the aims of the programme.

\section{Conclusion}

This article has highlighted a number of issues in teaching English to young learners. It has been shown that teachers are challenged, partly by lack of training, partly by lack of knowledge and partly by lack of resources. While government policy often results in time and energy being spent on introducing teachers to contemporary approaches advocated in the (mainly western) literature, training of this kind does not necessarily serve teachers well. Globally, teachers identify teaching skills as a particular challenge to which training courses need to respond. Addressing differentiation is another challenge that could be met by a range of responses from training courses to course book materials and it is certainly an issue that is both relevant and emergent.

Other challenges are more localised, as the case studies show. These include class size, teachers' own skills and confidence in English, and time pressures. Care needs to be taken to ensure that responses to local challenges are mediated by local educational 
conditions (Matsuda 2006) and strategies and solutions are found that build upon local teachers "sense of plausibility" (Prabhu, 1990). Kumaravadivelu (2001) argues that teachers should be helped to 'develop the knowledge and skill, attitude, and autonomy necessary to construct their own context-sensitive pedagogic knowledge' (p. 541) and this must surely be the aim of all teacher education.

\section{References}

Ahn, K., (2011) Learning to teach under curriculum reform: The practicum experience in South Korea. In K. E. Johnson, K.E. \& P. Golombek (Eds), Research on second language teacher education (pp. 239 - 253). New York: Routledge.

Author 1 and Mann, 2011

Authors 1,2,3, 2011

Baker, W. (2008). A critical examination of ELT in Thailand: The role of cultural awareness. RELC Journal, 39(1), 131-146. http://dx.doi.org/10.1177/0033688208091144

Bailey, K.M. (1996) Working for washback: a review of the washback concept in language testing.Language Testing, 13/3 257- 279doi: 10.1177/026553229601300303

Block, D., Gray, J., \& Holborow, M. (2012) Neoliberalism and Applied Linguistics. London: Routledge.

Brock-Utne, B., \&Holmarsdottir, H. B. (2004). Language policies and practices in Tanzania and South Africa: Problemsproblems and challenges. International Journal of Educational Development, 24(1), 67-83. http://dx.doi.org/10.1016/j.bbr.2011.03.031

Butler, Y. G. (2004). What level of English proficiency do elementary school teachers need to attain to teach EFL? Case studies from Korea, Taiwan, and Japan. TESOL Quarterly, 38(2), 245. http://dx.doi.org/ 10.2307/3588380

Butler, Y. G. (2005). Comparative perspectives towards communicative activities among elementary school teachers in South Korea, Japan and Taiwan.Language Teaching Research, 9(4), 423-446. http://dx.doi.org/10.1191/1362168805lr176oa

Butzkamm, W. (2003). We only learn language once. The role of the mother tongue in FL classrooms: Death of a dogma. The Language Learning Journal, 28(1), 29-39. http://dx.doi.org/10.1080/09571730385200181

Cameron, L. (2001). Teaching languages to young learners. Cambridge: Cambridge University Press.

Cameron, L. (2003). Challenges in ELT from the expansion in teaching children.ELT Journal 57(2), 105-112. http://dx.doi.org/10.1093/elt/57.2.105 
Carless, D. (2004).Issues in Teachers' Reinterpretation of a Task-Based Innovation in Primary Schools.TESOL Quarterly, 38(4), 639-662. http://dx.doi.org/10.2307/3588283

Chakraborty, T. \& Kapur, S. (2008). English language premium: Evidence from a policy experiment in India. St. Louis: Washington University in St. Louis.

Coleman, H. (2011). Dreams and Realities: Developing Countries and the English Language. London: The British Council

Conteh, J. (2007). Bilingualism in mainstream primary classrooms in England.InZ. Hua, P. Seedhouse, L. Wei \& V. Cook (Eds),Language learning and teaching as social interaction (pp. 185-198).London: Palgrave Macmillan.

Coupland, N. (2012) The Handbook of Language and Globalization. London: WileyBlackwell

Creese, A. and Blackledge, A. (2010).Translanguaging in the bilingual classroom: A pedagogy for learning and teaching?.The Modern Language Journal, 94(1), 103-115. http://onlinelibrary.wiley.com/doi/10.1111/j.1540-4781.2009.00986.x/full

de Vaus, D. (2002). Surveys in social research. London: Routledge.

Dörnyei, Z. (2009). Questionnaires in second language research: Construction, administration and processing. New York: Lawrence Erlbaum.

Edge, J. (Ed.) (2006) Relocating TESOL in an age of Empire. Basingstoke: Palgrave Macmillan

Enever, J. (Ed.). (2011). ELLiE.Early language learning in Europe.London, UK: British Council

Enever, J., \& Moon, J. (2009). New global contexts for teaching primary ELT: Change and challenge. In J. Enever, J. Moon \& U. Raman (Eds.), Young learner English language policy and implementation: International perspectives (pp. 5-21). Reading: Garnet Education.

García, O. (2009). Bilingual education in the $21^{\text {st }}$ century. Oxford, Wiley Blackwell

Ghatage, M. M. (2009). Introduction of English from grade 1 in Maharashtra, India. In J. Enever, J. Moon \& U. Raman (Eds), Young learner English language policy and implementation: International perspectives (pp. 45-51). Reading: Garnet Education

Gimenez, T. (2009). English at primary school level in Brazil: Challenges and perspectives. In J. Enever, J. Moon \& U. Raman (Eds), Young learner English language policy and implementation: International perspectives (pp. 53-59). Reading Garnet Education

Gorsuch, G. J. (2000). EFL educational policies and educational cultures: Approval of influences on teachers' activities communicative. TESOL Quarterly, 34(4), 675-710 http://www.ingentaconnect.com/content/tesol/tq/2000/00000034/00000004/art00003 
Harley, B. (1998) The role of focus-on-form tasks in promoting child L2 acquisition. In C. Doughty \& J. Williams (Eds), Focus on form in the classroom second language acquisition (pp.156-173). Cambridge: CUP

Ho, W. K. (2003). English language teaching in Asia today: An overview. In W. K. Ho\& R. Y. L. Wong (Eds), English language teaching in east Asia today: Changing policies and practices (pp. 1-32). Singapore: Eastern Universities Press

Ho, W. K., \& Wong, R. Y. L. (2003). Prologue: Aim, scope and concepts. In W. K. Ho\& R. Y. L. Wong (Eds), English language teaching in east Asia today: Changing policies and practices (pp. 1-32). Singapore: Eastern Universities Press

Hoque, S. (2009).Teaching English in primary schools in Bangladesh: Competencies and achievements. In J. Enever, J. Moon \& U. Raman (Eds), Young learner English language policy and implementation: International perspectives (pp. 61-69). Reading: Garnet Education

Hu, G. (2002). Potential cultural resistance to pedagogical imports: The case of communicative language teaching in China. Language Culture And Curriculum, 15(2), 93-105. http://dx.doi.org/10.1080/07908310208666636

Hu, G. (2005). Contextual influences on instructional practices: A Chinese case for an ecological approach to ELT. TESOL Quarterly, 39(4), 635-660. Retrieved from http://www.jstor.org/stable/3588525

$\mathrm{Hu}, \mathrm{Y}$. (2007). China's foreign language policy on primary English education: What's behind it? Language Policy, 6, 359-376. http://dx.doi.org/10.1007/s10993-007-9052-9

Inal, D. (2009). The early bird catches the worm: The Turkish case. In J. Enever, J. Moon \& U. Raman (Eds), Young learner English language policy and implementation: International perspectives (pp. 71-78). Reading: Garnet Education

Jenkins, J. (2000) Thephonology of English as an international language. Oxford: Oxford University Press

Jin, L., \& Cortazzi, M. (2003). English language teaching in China: A bridge to the future. In W. K. Ho \& R. Y. L. Wong (Eds), English language teaching in east Asia today: Changing policies and practices (pp. 131-145). Singapore: Eastern Universities Press

Johnson, R. B., Onwuegbuzie, A. J., \& Turner, L. A. (2007).Toward a definition of mixed methods research.Journal of Mixed Methods Research, 1(2), 112-133. http://dx.doi.org/10.1177/1558689806298224

Johnstone, R. (2009). An early start: What are the key conditions for generalized success? In J. Enever, J. Moon \& U. Raman (Eds), Young learner English language policy and implementation: International perspectives (pp. 31-41). Reading: Garnet Education 
Kirkgöz, Y. (2009). English language teaching in Turkish primary education. In J. Enever, J. Moon \& U. Raman (Eds), Young learner English language policy and implementation: International perspectives (pp. 189-195). Reading: Garnet Education

Kuchah, K. (2009). Early bilingualism in Cameroon: Where politics and education meet. In J. Enever, J. Moon \& U. Raman (Eds), Young learner English language policy and implementation: International perspectives (pp. 87-94). Reading: Garnet Education

Kumaravadivelu, B. (2001) Toward a post-method pedagogy. TESOL Quarterly, 35, 537 560.

http://onlinelibrary.wiley.com.openathensproxy.aston.ac.uk/doi/10.1002/tesq.2001.35. issue-4/issuetoc

Kumaravadivelu, B. (2011) Language Teacher Education for a Global Society: A Modular Model for Knowing, Analyzing, Recognizing, Doing, and Seeing. Abingdon: Routledge

Kunnan, A. J. (2005). Language assessment from a wider context. In Hinkel, E. (Ed.), Handbook of research in second language teaching and learning (pp.779 794).Mahwah, New Jersey: Routledge

Lamb, M. (2011). A 'Matthew Effect' in English language education in a developing country context. In Coleman, H. (Ed.), Dreams and realities: Developing countries and English language (pp. 191-211). London: The British Council

Li, D. (1998). "It's always more difficult than you plan and imagine": Teachers' perceived difficulties in introducing the communicative approach in South Korea. TESOL Quarterly, 32(4), 677-703. http://dx.doi.org/10.2307/3588000

Littlewood, W. (2007).Communicative and task-based language teaching in East Asian classrooms.Language Teaching, 40(03), 243.

http://dx.doi.org/10.1017/S0261444807004363

Lugossy, R.(2008) "I will think about this...” A case study with a lower primary school teacher of English. In R. Lugossy, J. Horváth\& M. Nikolov (Eds),UPRT 2008: Empirical studies in English applied linguistics. Pécs: Lingua Franca Csoport http://mek.niif.hu/07500/07558/07558.pdf

Macaro, E. (2005). Codeswitching in the L2 classroom: A communication and learning strategy. In E. Llurda (Ed.), Non-native language teachers: Perceptions, challenges and contributions to the profession (pp. 63-84). New York: Springer

Mathew, R., \&Pani, S. (2009). Issues in the implementation of teaching English for young learners (TEYL): A case study of two states in India. In J. Enever, J. Moon \& U. Raman (Eds), Young learner English language policy and implementation: International perspectives (pp. 113-120). Reading: Garnet Education

Matsuda, A. (2006) Negotiating ELT assumptions in EIL classrooms.InEdge, J. (Ed.) Relocating TESOL in an age of Empire (pp. 158 -170). Basingstoke: Palgrave Macmillan 
Mee, C. Y. (2003). English language teaching in Singapore today. In W. K. Ho\& R. Y. L. Wong (Eds), English language teaching in east Asia today: Changing policies and practices (pp. 351-374). Singapore: Eastern Universities Press

Mitchell, R., \& Lee, J. H.-W. (2003). Sameness and difference in classroom learning cultures: Interpretations of communicative pedagogy in the UK and Korea. Language Teaching Research, 7(1), 35-63. http://dx.doi.org/10.1191/13621688031r114oa

Morse, J. M. (2010). Simultaneous and sequential qualitative mixed method designs. Qualitative Inquiry, 16(6), 483-491. http://dx.doi.org/10.1177/1077800410364741

Nunan, D. (2003). The impact of English as a global language on educational policies and practices in the Asia-Pacific region.TESOLQuarterly, 37(4), 589-613. http://dx.doi.org/10.2307/3588214

Nur, C. (2003). English language teaching in Indonesia: Changing policies and practical constraints. In W. K. Ho\& R. Y. L. Wong (Eds.), English language teaching in east Asia today: Changing policies and practices (pp. 163-172). Singapore: Eastern Universities Press

Pandian, A. (2003).English language teaching in Malaysia today. In W. K. Ho\& R. Y. L. Wong (Eds.), English language teaching in east Asia today: Changing policies and practices (pp. 269-292). Singapore: Eastern Universities Press

Pillar, I., \& Cho, J. (2013).Neoliberalism as language policy.Language in Society 42, 23 - 44. http://dx.doi.org/10.1017/S00474045120000887

Pinter, A. (2006). Teaching young language learners. Oxford: Oxford University Press

Pinter, A. (2011). Children learning second languages. Palgrave Macmillan: London

Prabhu, N.S. (1990). There is no best method - why?.TESOL Quarterly 24 (2), 161 - 176. http://www.jstor.org/stable/3586897

Prapaisit de Segovia, L., \&Hardison, D. M. (2008).Implementing education reform: EFL teachers' perspectives. ELT Journal, 63(2), 154-162. http://dx.doi.org/10.1093/elt/ccn024

Reis, H. T., \& Judd, C.M. (2000) Handbook of Research Methods in Social and Personality Psychology: A Toolbox for Serious Researchers. Cambridge: Cambridge University Press

Richards, K., Ross, S. \&Seedhouse, P. (2012).Research methods for applied language studies.Abingdon: Routledge

Saergeant, P. \& Erling, E.J. (2011). The discourse of English as a language for international development: Policy assumptions and practical changes. In Coleman, H. (Ed.) Dreams and realities: Developing Countries and English Language (pp. 255- 274). London: The British Council 
Shamim, F. (2012).Teaching large classes. In Burns, A., \& Richards, J. C. (Eds.), The Cambridge guide to pedagogy and practice in second language teaching (pp. 95102). New York: CUP

Tinker Sachs, G. (2009) Taking risks in task-based teaching and learning. Asian Journal of English Language Teaching, 19, 91-112. Retrieved from http://www.cuhk.edu.hk/ajelt/vol19/abstract/a04.pdf

Wedgwood, R. (2007). Education and poverty reduction in Tanzania. International Journal of Educational Development, 27, 383-396. Retrieved from http://hakielimu.org/files/publications/document102edu_poverty_reduction_tz_en.pdf

Williams et. al 